\title{
УДК 658.58
}

\section{РОЗРОБЛЕННЯ СТРАТЕГІЇ І ТАКТИКИ УПРАВЛІННЯ ПІДПРИСМСТВОМ У СУЧАСНІЙ УКРАЇНІ}

\author{
Марина Єщенко; Вікторія Михайличенко
}

\author{
Донбаська національна академія будівництва і архітектури, \\ Краматорськ, Україна
}

\begin{abstract}
Резюме. Розкрито сутність розроблення стратегї на підприємстві. Вивчено тактику управління підприсмством у сучасних ринкових умовах. Досліджено роль стратегї в управлінні перспективним розвитком підприємства. Тому щуо, діючи в умовах нестабільного середовища ринкової економіки, підприємства України можуть досягти успіху в бізнесі тільки тоді, коли їм вдасться передбачати зміни і відповідно вживати запобіжні адаптивні заходи щчодо них. Розглянуто питання забезпечення стабільної ефективної діяльності підприємств у довготривалому періоді в умовах постійного ускладнення $i$ нестабільності зовнішнього середовища. Проведено пошук нових підходів до управління вітчизняним підприємством як суб'єктом господарювання. Вивчено тактику підприємства як засіб, який забезпечує реалізачію наміченої стратегії. Тактика визначає конкретні короткотермінові завдання, які забезпечують постійне наближення до поставленої мети. Вона розробляється $i$ впроваджується керівництвом і працівниками у низових ланках. Тактика розробляється на основі стратегії, але, в свою чергу, в процесі ії реалізації здійснюється уточнення стратегії. Взаємозв'язок між стратегією $i$ тактикою є складним. У кожному підприємстві на різних рівнях управління використовуються свої особливі стратегії, всі вони побудовані за ієрархічним приничиом: від корпоративної (загальної) до функиіональної. Розглянуто процес вибору та формування стратегї як останній етап у процесі розроблення загальної стратегї підприємства: деякі компанії вважають дочільним копіювання стратегї іншого успішного підприємства, але будь-яка стратегія є складним та комплексним елементом системи менеджменту і скопіювати ї̈ повністю неможливо й ие не буде ефективним управлінським рішенням. На основі дослідження проаналізовано основні складові тактики управління підприємством: заплановані дії $i$ заходи з реалізації стратегії; методи, прийоми, підходи, стилі реалізації стратегії $i$ проведення змін; дї̈ й заходи у відповідь на зміну умов діяльності підприємства; методи управління стратегічними змінами. Запропоновано рекомендації щзодо розроблення стратегій управління підприємством у сучасних умовах, а також схематичний зв 'язок між стратегією й тактикою управління підприємством.
\end{abstract}

Ключові слова: менеджмент, перспектива, розвиток, розроблення стратегії, стратегія, тактика

\section{UDC 658.58}

\section{DEVELOPMENT OF ENTERPRISE MANAGEMENT STRATEGIES AND TACTICS IN MODERN UKRAINE}

\author{
Maryna Yeshchenko; Viktoria Mykhailichenko
}

\author{
Donbas National Academy of Civil Engineering and Architecture, \\ Kramatorsk, Ukraine
}

\begin{abstract}
Summary. The essence of the enterprise strategy development is revealed in this paper. Tactics of enterprise management under modern market conditions is considered. The role of strategy in the management perspective enterprise development is investigated, since operating under unstable environment conditions of
\end{abstract}


market economy, the Ukrainian enterprises can run their business successfully if they succeed in forecasting the changes and thus in accepting preventive adaptive measures related to them. The problem of providing the stable effective enterprises activity in long-term period under the conditions of constant environment complication instability is considered. The search of new approaches to the management of national enterprise as business entity is performed. The enterprise tactics as the mean providing planned strategy realization is investigated. Tactics determines certain short-term tasks which provide constant approaching to the target goal. It is developed and implemented by administration and first-line workers. Tactics is developed on the basis of strategy, and therefore, the strategy clarification is carried out during the process of its realization. Interrelation between strategy and tactics is difficult. Special strategies are used at every enterprise on different management levels, all of them are built according to hierarchical principle: from corporate (general) to functional. The process of choosing and formulating the strategy is identified as the last step in the process of developing the overall enterprise strategy: some companies consider it appropriate to copy the strategy of another successful enterprise, but any strategy is compound and complex element of the management system and it cannot be copied completely and be effective management solution. Basic components of the enterprise management tactics such as: planned actions and measures concerning strategy implementation; methods, techniques, approaches, styles of strategy and changes implementation; actions and measures as the response to the change of enterprise operational conditions; methods of strategic changes management are analyzed on the basis of investigation. Recommendations concerning the development of enterprise management strategies under modern conditions, as well as schematic connection between the enterprise management strategy and tactics are proposed in this paper.

Key words: strategy, prospect, management, strategy development, tactics.

https://doi.org/10.33108/galicianvisnyk_tntu2020.03.157

Received 21.04.2020

Постановка проблеми. Для ефективного функціонування в сучасних умовах ринкової економіки підприємствам потрібно визначити напрям подальшого розвитку, який стане запорукою їхньої успішної діяльності. В таких умовах підприємства формують цілі, пов’язані з вибором і закріпленням певної частини ринку (ринкової ніші), формуванням та підтриманням конкурентоспроможного статусу.

Для вирішення даних проблем існує розроблення обгрунтованої стратегії подальшого розвитку підприємства, яка визначає напрямок його поведінки на ринку 3 урахуванням змін зовнішнього середовища, дозволяє сформулювати глобальну мету існування компанії та визначити ресурси, які необхідно залучити для досягнення цілей. За відсутності стратегічного плану керівникові буде важко реагувати на стрімкі зміни зовнішнього середовища та приймати правильні управлінські рішення.

Аналіз останніх досліджень і публікацій. Питанням вивчення стратегії й тактики управління підприємством було присвячено багато наукових праць не лише вітчизняних, але й зарубіжних науковців, а саме: I. Ансоффова, В. Білошапка, В. Василенка, В. Винокурова, А. Градова, К. Дрела, Г. Клєйнера, В. Маркова, А. Наливайка, Н. Подольчака, С. Тараненка, А. Томпсона. Також вагомий внесок у розвиток стратегічного управління зробили такі вчені: Д. Аакер, Х. Віссєм, У. Кінг, Д. Кліланд, Г. Мінцберг, А. Дж. Стрікленд, О. Віханський, П. Забєлін, М. Круглов, В. Сфремов, В. Герасимчук, В. Пономаренко, О. Пушкар, О. Тридід, М. Туленков, 3. Шершньов, В. Щелкунов та інші.

Метою дослідження $є$ вивчення теоретичних аспектів розроблення стратегії $\mathrm{i}$ тактики управління підприємством та визначення рекомендацій щодо розроблення стратегій у сучасних ринкових умовах.

Постановка завдання. Для досягнення поставленої мети визначено такі наукові завдання: розкрити сутність стратегічного управління, визначити особливу його роль у керівництві підприємством.

Для вирішення поставлених завдань було використано такі методи: аналіз, синтез, узагальнення.

Виклад основного матеріалу. Стратегія визначає загальний напрямок і спосіб використання засобів для досягнення поставленої мети. Стратегія - це багатоплановий управлінський процес, який допомагає формулювати та виконувати перспективні цілі 
підприємства й дозволяє ефективно взаємодіяти 3 зовнішнім середовищем [1]. Розроблення стратегій підприємств - це досить складний і тривалий процес, враховуючи постійне переоцінювання й періодичну перевірку вибраних цілей, аналізуючи при цьому стан середовища діяльності самого підприємства.

Мета стратегічного управління - створення такої динамічної системи управління, яка в умовах нестабільності й швидких змін середовища за допомогою розроблення й упровадження ефективних стратегій забезпечила б високу конкурентоспроможність підприємства і досягнення ним довготермінових стратегічних цілей [2].

Реальна стратегія підприємства складається не тільки з запланованих дій, а ще й 3 реакції на певні непередбачувані обставини. Стратегію слід розглядати як симбіоз запланованих дій (проактивна стратегія) та адаптивної реакції на ситуацію (реактивна стратегія) [3].

Стратегія - це не тільки продуманий абстрактний план, вона повинна коригуватися за рахунок додавання одних параметрів і відмови від інших у відповідь на ринкові зміни. Саме тому не потрібно планувати кожен крок, набагато краще створити загальний план і при потребі коригувати його.

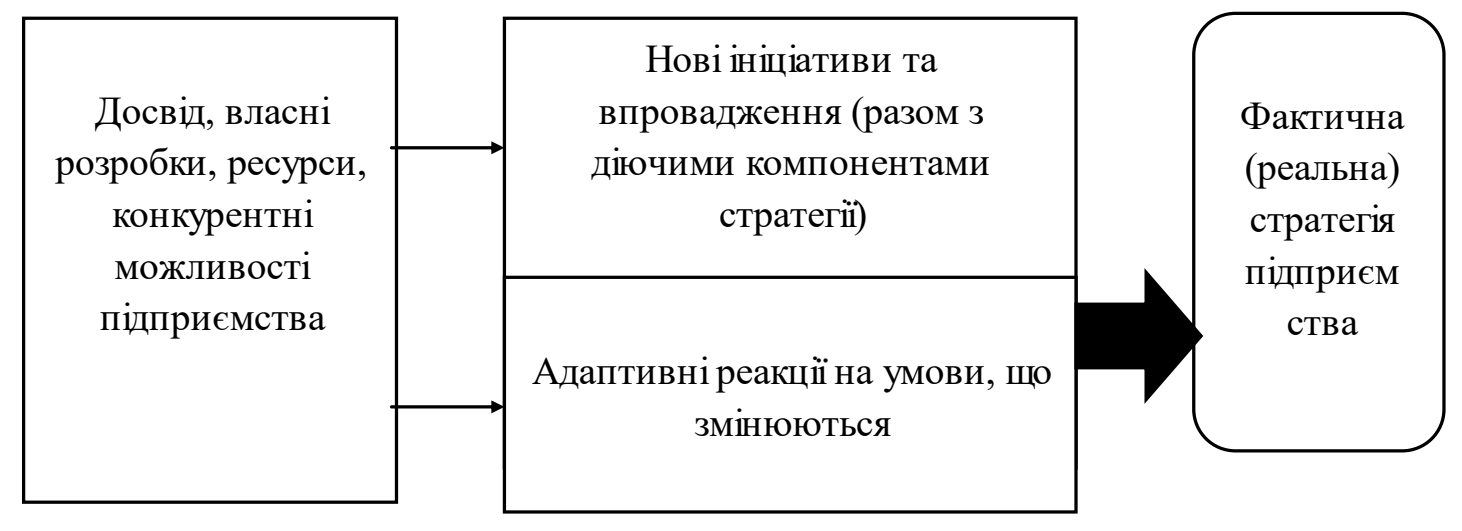

Рисунок 1. Склад реальної стратегії підприємства

Figure 1. The structure of real enterprise strategy

Співвідношення запланованої та реактивної частин стратегії залежить від умов зовнішнього середовища, стабільності ситуації на ринку та у країні в цілому. Чим більша ступінь нестабільності зовнішнього середовища, тим більшою буде частина реактивної (змінюваної) стратегії [3].

Уміння швидко реагувати на зміни зовнішнього середовища та коригувати стратегію залежить від майстерності менеджера-керівника. Можна сказати, що ефективність управління підприємством залежить від менеджерів, які розробляють стратегії підприємства та втілюють їх у життя.

Вибір та формування стратегії - це останній етап у процесі розроблення загальної стратегії підприємства. Деякі компанії вважають доцільним копіювання стратегії іншого успішного підприємства, але будь-яка стратегія є складним та комплексним елементом системи менеджменту і скопіювати ії повністю неможливо й це не буде ефективним управлінським рішенням.

Саме стратегічне управління є найважливішим засобом забезпечення успішного виживання підприємства в агресивному динамічному конкурентному середовищі, засобом його адаптації до змін у ньому. Відсутність орієнтирів, місії й цільової спрямованості розвитку підприємства, можливості розпізнавання впливу його 
зовнішнього оточення й адекватної реакції на нього, а також здатності адаптуватися чи навіть активно впливати на це середовище, на жаль, робить більшість українських підприємств безпомічними нині й безперспективними у майбутньому. У випадку застосування стратегічного управління на підприємстві в кожен момент буде фіксуватися інформація про те, що підприємство повинно робити в даний час, щоб досягти бажаної мети у майбутньому, виходячи при цьому з того, що оточення й умови функціонування підприємства будуть змінюватися. При цьому слід мати на увазі, що вибір стратегії та іiі виконання є основними частинами стратегічного управління. А продумана стратегія дасть змогу вирішити питання узгодженості виробничих i відтворювальних процесів, скоординувати діяльність різних підсистем і тим самим підвищити потенціал підприємства та його адаптивні можливості. Застосування стратегічного підходу до діяльності підприємства сприятиме створенню системи, в якій конкретні управлінські рішення забезпечують збалансований розвиток усіх компонентів діяльності підприємства відповідно до умов зовнішнього середовища.

Кожна організація має свої особливі риси, які треба врахувати при формуванні стратегії й тільки при врахуванні цих особливостей підприємство може бути конкурентоспроможним на ринку.

Процес вибору стратегії включає три етапи: розроблення стратегічних альтернатив (створення найбільшої кількості альтернативних стратегій розвитку підприємства), їх оцінювання (проводиться 3 метою оцінювання розроблених конкретних стратегічних варіантів, їх придатності для конкретного підприємства) та вибір найефективнішої стратегії серед запропонованих варіантів [4].

Далі розглянемо сутність тактичного управління підприємством у сучасних умовах та її взаємозв'язок із стратегічним управлінням.

Існує два основних підходи до визначення сутності тактики. Найчастіше під тактикою розуміють поточні плани з реалізації стратегії, короткотермінові стратегії, дії 3 реалізації стратегій. 3 іншого боку, тактикою також $є$ сукупність засобів, прийомів і методів досягнення цілей у конкретних умовах, тобто те, як реалізуються стратегії, за допомогою яких методів вони здійснюються. Обидва ці аспекти $є$ важливими й невід'ємними елементами розгляду тактики [5].

Тактика визначає конкретні короткотермінові завдання, які забезпечують постійне наближення до поставленої мети. Схематично зв’язок між стратегією i тактикою зображено на рисунку 2.

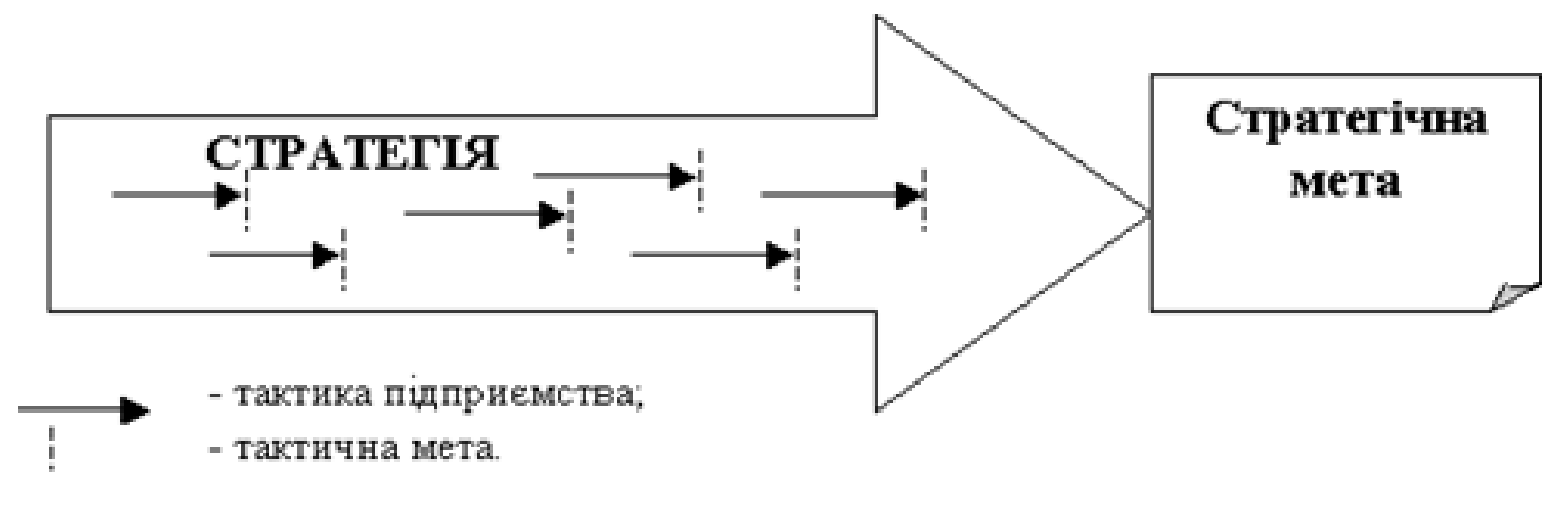

Рисунок 2. Взаємозв'язок стратегії і тактики підприємства

Figure 2. The relationship between enterprise strategy and tactics 
Основні складові тактики управління підприємством:

- заплановані дії та заходи з реалізації стратегії;

- методи, прийоми, підходи, стилі реалізації стратегії й проведення змін;

- дії і заходи у відповідь на зміну умов діяльності підприємства;

- методи управління стратегічними змінами [6].

Висновки. Стратегія - це багатоплановий управлінський процес, який допомагає формулювати та виконувати перспективні цілі підприємства й дозволяє ефективно взаємодіяти із зовнішнім середовищем. Підприємство, організовуючи виробничу діяльність, визначає свою стратегію (стратегічні цілі, завдання) й тактику. Стратегічні завдання підприємства повинні визначати напрями його діяльності на перспективу: вдосконалення своєї продукції; забезпечення результативності у технології; зниження собівартості; підвищення якості; досягнення ефективності при низьких витратах виробництва; забезпечення достатньої рентабельності; визначення конкретних параметрів досягнення результату. Стратегія підприємства передбачає створення комплексної системи заходів, спрямованих на досягнення перспективних параметрів ефективності, реалізацію головної мети підприємства.

Тактика підприємства - засіб, який забезпечує реалізацію наміченої стратегії. Тактика визначає конкретні короткотермінові завдання, які забезпечують постійне наближення до поставленої мети. Вона розробляється і впроваджується керівництвом і працюючими у низових ланках. Тактика розробляється на основі стратегії, але в свою чергу, в процесі іï реалізації здійснюється уточнення стратегії. Взаємозв'язок між стратегією і тактикою є складним. У кожному підприємстві на різних рівнях управління використовуються свої особливі стратегії, всі вони побудовані за ієрархічним принципом: від корпоративної (загальної) до функціональної.

Conclusions. Strategy is multidimensional administrative process promoting the formulation and execution of the enterprise perspective goals and making it possible to cooperate effectively with the environment. The enterprise while organizing productive activity, determines its strategy (strategic aims, tasks) and tactics. The strategic enterprise tasks should define the directions of its activity for long term: improvement of its products; support of technology effectiveness; decrease of cost value; quality improvement; achievement of efficiency with low production expenses; support of sufficient profitability; determination of certain parameters of the result achievement. The enterprise strategy anticipates the development of complex measures system, aimed at the achievement of advanced efficiency parameters, implementation of the enterprise main goal.

Enterprise tactics is the mean providing outlined strategy implementation. Tactics determines certain short-term tasks which provide constant approaching to the target goal. It is developed and implemented by administration and first-line workers. Tactics is developed on the basis of strategy, and therefore, the strategy clarification is carried out during the process of its realization. Interrelation between strategy and tactics is difficult. Special strategies are used at every enterprise on different management levels, all of them are built according to hierarchical principle: from corporate (general) to functional.

\section{Список використаної літератури}

1. Подольчак Н. Ю. Стратегічний менеджмент. Львів: Вид-во Національного університету «Львівська політехніка», 2006. 224 с.

2. Василенко В. О. Стратегічне управління: навчальний посібник. Київ: ЦУЛ, 2003. 396 с. 
3. Стратегічне управління підприємством. URL: https://pidruchniki.com/13500826/menedzhment/ strategichne_upravlinnya_pidpriyemstvom (дата звернення: 08.04.2020).

4. Стратегічне управління - сучасний варіант реалізації цільового підходу. URL: https://buklib.net/ books/24968/ (дата звернення: 08.04.2020).

5. Переваги стратегічного підходу до управління. URL: https://studfile.net/preview/5705900/page:2/ (дата звернення: 09.04.2020).

6. Тактика підприємства: сутність, особливості і взаємозв'язок зі стратегією. URL: http://www. rusnauka.com/30_NIEK_2009/Economics/54111.doc.htm (дата звернення: 09.04.2020).

\section{References}

1. Podol'chak N. Yu. Stratehichnyy menedzhment. L'viv: Vyd-vo Natsional'noho universytetu "L'vivs'ka politekhnika", 2006. $224 \mathrm{p}$.

2. Vasylenko V. O. Stratehichne upravlinnya: navchal'nyy posibnyk. Kyiv: TsUL, 2003. 396 p.

3. Stratehichne upravlinnya pidpryyemstvom. URL: https://pidruchniki.com/13500826/menedzhment/ strategichne_upravlinnya_pidpriyemstvom (accessed: 08.04.2020).

4. Stratehichne upravlinnya - suchasnyy variant realizatsiyi tsil'ovoho pidkhodu. URL: https://buklib.net/ books/24968/ (accessed: 08.04.2020).

5. Perevahy stratehichnoho pidkhodu do upravlinnya. URL: https://studfile.net/preview/5705900/page:2/ (accessed: 09.04.2020)

6. Taktyka pidpryyemstva: sutnist', osoblyvosti i vzayemozv"yazok zi stratehiyeyu. URL: http://www. rusnauka.com/30_NIEK_2009/Economics/54111.doc.htm (accessed: 09.04.2020). 